\title{
44 . . . AL ESTILO DE INGLATERRA SEGÚN LA ÚLTIMA MODA". FIGURINES INGLESES. EDICIÓN PARA ESPAÑA 1824-25 DE RUDOLPH ACKERMANN ${ }^{1}$
}

\author{
MANUEL PÉREZ SÁNCHEZ \\ Universidad de Murcia \\ mperezsa@um.es \\ JOSÉ MIGUEL LÓPEZ CASTILLO \\ Universidad de Murcia \\ jm.lopez@um.es
}

\begin{abstract}
Resumen: Desde el último tercio del siglo XVIII, las estampas de figurines relacionadas directamente con la apariencia, el gusto y la moda, difundidas desde la prensa, tienen en España una especial significación a la hora de orientar a las élites urbanas e ilustradas. Se trataba, en definitiva, de estar al día de las novedades y adelantos que se producían en todos aquellos objetos y elementos destinados a priorizar el estatus y la elegancia conforme a los dictados que se gestaban en las grandes capitales europeas que marcaban las pautas de la distinción. Londres y lo inglés, junto a los figurines parisinos, comenzó a formar parte de los criterios estéticos de la alta sociedad española, que participó a través de la elección de lo británico como símbolo de una nueva modernidad. Buen ejemplo de ello es el volumen de grabados, editados por la Casa Ackermann, bajo el título Figurines ingleses. Edición para España 1824-25, que se analiza en este estudio.
\end{abstract}

Palabras clave: Figuras / moda inglesa / siglo XIX / artes decorativas / indumentaria / Rudolph Ackermann.

\section{“... AFTER THE ENGLISH STYLE, IN THE LATEST FASHION”. FIGURINES INGLESES. EDICIÓN PARA ESPAÑA 1824-25 OF RUDOLPH ACKERMANN}

\begin{abstract}
Since the last third of the eighteenth century, the prints of figurines directly related to appearance, taste and fashion, spread from the press, they have a special significance in Spain when it comes to guiding urban and enlightened elites. It was, in short, a question of being up to date with the developments and advances that were occurring in all those objects and elements aimed at prioritizing status and elegance according to the dictates that were drawn in the great European capitals that set the standards of distinction. London and its culture, together with the Parisian figurines, began to form part of the aesthetic criteria of Spanish high society who participated through the election of the British as a symbol of a new modernity. A good example of this is the volume of engravings, edited by Ackermann House, under the title Figurines ingleses. Edición para España 1824-25, which is analyzed in this study.
\end{abstract}

Key words: Figurines / English fashion / 19 century / decorative arts / clothing / Rudolph Ackermann.

Como sabemos, el arte, la estética, el gusto y la moda por lo general siempre han ido de la mano de la nobleza y las monarquías europeas reinantes. En el caso de España, la Casa de Borbón ejerció desde principios del siglo XVIII un cambio sus- tancial en los hábitos y el paladar cortesano y, por ende, en el de la gran mayoría de la sociedad española del momento. El gusto por lo francés comienza a germinar en un país anclado en la más rancia tradición del período monárquico anterior;

\footnotetext{
* Fecha de recepción: 15 de enero de 2020 / Fecha de aceptación: 20 de septiembre de 2020.

1 El presente estudio se ha realizado dentro del contexto de la ayuda de la Beca FPU (FPU17/00039) del Ministerio de Educación, Cultura y Deporte y del Proyecto de Investigación I+D Excelencia HAR2017-83666-P, El documental de arte en España
} (1939-1975), financiado por el Ministerio de Economía, Industria y Competitividad. 
en algunos casos recibido con recelo y rechazo, ${ }^{2}$ en otros como un impulso de modernidad y nuevas esperanzas de cambios. Gracias a estos nuevos estímulos provenientes de Francia sobre el nuevo "gusto" y "decencia" de los trajes, posteriormente se fueron incorporando a la estética del vestir y las artes decorativas los cambios inmediatos que emanaban de las corrientes anglosajonas de finales del setecientos. Por tal motivo, observaremos que, en aspectos relacionados con el mobiliario, decoración, objetos de lujo e incluso con algunas formas de vestir, se perpetuarán los nuevos gustos por determinadas novedades inglesas durante el siglo siguiente. Eso sí, casi siempre desarrolladas y extendidas desde la capital de la moda en Occidente desde el siglo XVII, París.

En este estudio pretendemos poner de relieve esa influencia británica en las artes decorativas $y$, de forma más mesurada, en el vestir femenino dentro las colecciones de figurines de principios del siglo XIX, fundamentalmente en una que se publicó entre los años 1824 y 1825: Figurines ingleses. Edición para España -actualmente se conserva una copia en la Biblioteca Nacional de España bajo la signatura ER/3780- y que, en este caso, procedía desde otro gran centro difusor de novedades, Londres. Este ejemplar fue editado por el prestigioso librero de origen alemán afincado en la capital del Támesis Rudolph Ackermann (17641834), ${ }^{3}$ al cual se debe una obra cumbre: la galería de pinturas, dibujos, acuarelas y grabados titulada Repository of Arts (1809-1828) compuesta de 40 volúmenes. ${ }^{4}$ Curiosamente, en esta obra se incluyeron unas láminas coloreadas: "representando los Arabescos y ornamentos de las salas de la famosa Alhambra de Granada". ${ }^{5}$ La firma de la empresa de este editor viene plasmada en tres lámi- nas de la reseñada colección de figurines, en concreto las destinadas a objetos suntuarios en las que se muestran: tres modelos de sillas, varios ejemplos de cortinas y, por último, la estampa de un carruaje ("Carretela de verano"), donde se puede leer "published April 1825, at. R. Ackermann's 101, Strand, London". ${ }^{6}$

Ackermann, en su interés por la captación de clientes para sus carruajes, comenzó a divulgar desde 1791 grabados de sus diseños para publicitarlos. Fue de este modo como se introdujo en el mundo de las artes gráficas. ${ }^{7}$ Con el fin de difundir su obra en España e Hispanoamérica en esta prestigiosa casa trabajaron varios españoles para traducir los textos al castellano, como el literato bilbaíno José de Urcullu quien dedicó a Ackermann un tributo de gratitud en El Instructor tras su fallecimiento. ${ }^{8}$

Asimismo, nos interesará contrastar esta colección con las aportaciones dadas en la prensa española de finales del siglo XVIII y principios de la siguiente centuria -en concreto, el Diario de Madrid o el Periódico de las Damas-, ya que nos desvelan datos de fundamental importancia al rastrear diversas alusiones a una estética refinada y adecuada, tanto en ciertos objetos de lujo como en algunas prendas, las cuales casi siempre se corresponden con las novedades del momento y que al mismo tiempo avalaban la modernidad del producto en cuestión, en base a las formulaciones inglesas.

En materia de indumentaria ya está más que estudiado que el desarrollo de esta corrió a cuenta de las creaciones parisinas, pero hay señalar que el país galo también se basó en determinadas corrientes que emanaron de Inglaterra en cuestiones relacio-

\footnotetext{
2 Recordemos que, en el caso del reino de Murcia, las censuras contra los excesos en el vestir llevadas a cabo por el obispo de la Diócesis de Cartagena, Luis Belluga y Moncada, según los postulados eclesiásticos de aquel siglo que se comenzaron a desarrollar bajo la influencia extranjera en la indumentaria femenina de este territorio, se basaban, entre otros, en los escotes de los jubones y cotillas de las mujeres. Véase BELLUGA Y MONCADA, Luis, 1711. Además, por lo general, en muchos diarios y periódicos de finales del siglo XVIII y principios del XIX aparecen numerosos discursos, en forma de crítica o defensa, sobre las influencias extranjeras en el vestir español. Véase también a modo de ejemplo el Diario de Madrid o el Periódico de las Damas.

${ }^{3}$ Véase HARRIS, Katherine. "The legacy of Rudolf Ackermann and Nineteenth-Century British Literary Anuals". 2015. En línea.

${ }^{4}$ DURÁN LÓPEZ, Fernando, 2015, p. 1-2.

${ }^{5}$ El Instructor. Febrero de 1836, n 26, p. 46.

${ }^{6}$ Gracias a las investigaciones de Jesusa Vega, se sabe que este editor ya tenía relaciones con personalidades españolas. Por tal hecho posibilitaría el interés de Ackerman por el mercado español, siendo una de las figuras extranjeras que más llegó al público en España. VEGA, Jesusa, 2018, p. 190.

7 Además, y esto justifica en parte su incursión en España, contrató a grandes ilustradores y publicistas y creó una escuela de dibujo. Además de ingleses, también contrató a emigrantes alemanes, franceses y exilados españoles: Blanco White, José Joaquín Mora, Pablo de Mendíbil, José de Urcullu, Joaquín Lorenzo Villanueva, Esteban Pastor o José Núñez Arenas. DURÁN LÓPEZ, Fernando, 2015, p. 1-3.

8 Véase El Instructor. Julio de $1834, n^{\circ} 7$, p. 219.
} 
nadas con el nuevo gusto en la moda. Si bien es cierto que sobre los asuntos del traje -esencialmente el de la mujer- se han abordado diversos enfoques desde finales del siglo XIX y todo el siglo $\mathrm{XX}$, en estas últimas décadas la nómina bibliográfica sobre preceptos indumentarios y de moda de los siglos XVIII y XIX (aristocrática o popular) se ha visto incrementada con una grandiosa variedad de publicaciones sobre investigaciones dedicadas a la historia del traje o la moda. ${ }^{9}$ Aunque este último concepto, según la afirmación de Ana María Velasco, hay que comprenderlo como algo muy general, por lo que hay que diferenciar entre historia del traje e historia de la moda pues "ir a la moda son dos realidades muy diferentes". ${ }^{10} \mathrm{Al}-$ gunos de estos estudios -muchos de ellos monográficos-, tanto nacionales como internacionales, constituyen un amplísimo estado de la cuestión sobre aspectos vinculantes a piezas textiles o indumentaria en general. ${ }^{11}$ Al hilo de lo expresado, el Periódico de las Damas ${ }^{12}$ advertía que

es necesario no obstante fijar el sentido de esta palabra moda, cuya significación es muy vaga é indeterminada. Generalmente hablando se llama moda cualquier uso ó invencion que el capricho de los hombres ha establecido en las sociedades. [...] Pero la moda en sentido rigoroso, consiste en el uso que hacemos de todo aquello que sirve para el ornato de nuestros cuerpos, como son los vestidos y sus aderentes. ${ }^{13}$

\section{Antecedentes: centros y formas de difusión de la moda}

Para estos asuntos, antes de la aparición de las revistas de novedades, los mercados de la moda y los objetos suntuarios se difundían en los diferentes países europeos, entre otros muchos medios, a través de estampas y grabados que procedentes de los grandes centros artísticos (Francia o Inglaterra) alcanzaban a la casi totalidad de la sociedad urbana del siglo XVIII mediante su venta en librerías o imprentas generalmente. Estos figurines se anunciaban previamente en los diarios de avisos y otras noticias ${ }^{14}$ los cuales ya se prodigaban en España durante la segunda mitad de esta centuria y principios de la siguiente. Como veremos, las láminas de figurines no mostraban las modas única y exclusivamente dedicadas a la indumentaria pues, además, incluían las nuevas corrientes, estéticas y adelantos en mobiliario o artes decorativas.

Dentro de este margen de ideas, según la observación de Pablo Pena, ${ }^{15}$ la influencia parisina en la moda española fue notable en cuanto a la londinense, puesto que la etiqueta británica en el vestir finalmente quedó definida desde las primeras décadas del siglo XIX prácticamente en el traje del hombre (el frac). Sin embargo -y en eso seguimos de acuerdo con la idea de Pena-, la influencia de la capital del Támesis en la moda europea en general fue más vaga pero mucho más diversa, pese

\footnotetext{
9 Dado que nuestro principal interés radica en corroborar esencialmente la influencia inglesa en diferentes campos de la moda y el buen gusto a principios del siglo, véanse como ejemplos de estudios sobre indumentaria, historia del traje o de la moda, entre otros a PUIGGARÍ, José. Monografía histórica é iconografía del traje. Valladolid: Maxtor, ed. facs. 2008; BOUCHER, François. Historia del traje en Occidente desde la antigüedad hasta nuestros días. Barcelona: Montaner y Simón S.A., 1967; RACINET, Auguste. Historia del vestido. Madrid: Libsa, $2^{\mathrm{a}}$ ed., 1992; RAVELLE, François. Marie Antoinette: reine de la mode et du goût. Paris: Parigramme, 2017; DAVIDSON, Hilary. Dress in the age of Jane Austen: regency fashion. New Haven: Yale University Press, 2019.

10 VELASCO MOLPECERES, Ana María, 2016, p. 37.

11 También véanse a SQUICCIARINO, Nicola. El vestido habla. Madrid: Ediciones Cátedra, 1990; MONTOYA RAMÍREZ, María Isabel (ed.). Moda y sociedad. La indumentaria: estética y poder. Granada: Universidad de Granada, 2002; SOUSA CONGOSTO Francisco de. Introducción a la historia de la indumentaria en España. Madrid: Ediciones Istmo, 2007; PENA GONZÁLEZ, Pablo. El traje en el Romanticismo y su proyección en España, 1828-1868. Madrid: Ministerio de Cultura, 2008; HART, Avril; NORTH Susan. La moda de los siglos XVII-XVIII en detalle. Barcelona: Ediciones Gustavo Gili, 2009; MARTínEZ ALCÁZAR, Elena. "No agrada la moda nueva por mejor, sino por nueva". Arenal, 2016, n 23-2, p. 375-401; CRESPO SÁNCHEZ, Francisco Javier. "Vestidos y adornos: la crítica a las apariencias externas a través de la prensa española (finales del siglo XVIII-siglo XIX)". Estudios Humanisticos. Historia, 2016, n 15, p. 137-155; WELCH, Evelyn (ed.). Fashioning the Early Modern. Dress, Textiles, and Innovation in Europe 1500-1800. New York: Oxford University Press, 2017.

12 Véase JIMÉNEZ MORELL, Inmaculada. La prensa femenina en España: (desde sus orígenes a 1868). Madrid: Ediciones de la Torre, 1992.

13 Periódico de las Damas. $1822, n^{\circ} 2$, p. 3-6

14 Uno de los principales medios de difusión para las nuevas modas antes de la venta de la colección de figurines parisinos en cuestión fue el Diario de Madrid. En concreto, en el n 5 del miércoles 5 de enero de 1791 se anunció a los lectores la subscripción: "á la obra de grabado intitulada: Muestras de trages y muebles decentes y de buen gusto", explicando que en esta colección se venderían diferentes estampas con los nuevos trajes masculinos y femeninos, al igual que peinados, nuevos muebles, adornos para habitaciones, nuevos modelos de coches, obras de platería, etc. Según lo reseñado en este periódico, la subscripción era para 36 estampas a 144 reales, siendo el lugar donde se vendían el despacho del Diario de Madrid, carrera de San Gerónimo.

15 PENA GONZÁLEZ, Pablo, 2007, p. 95-106.
} 


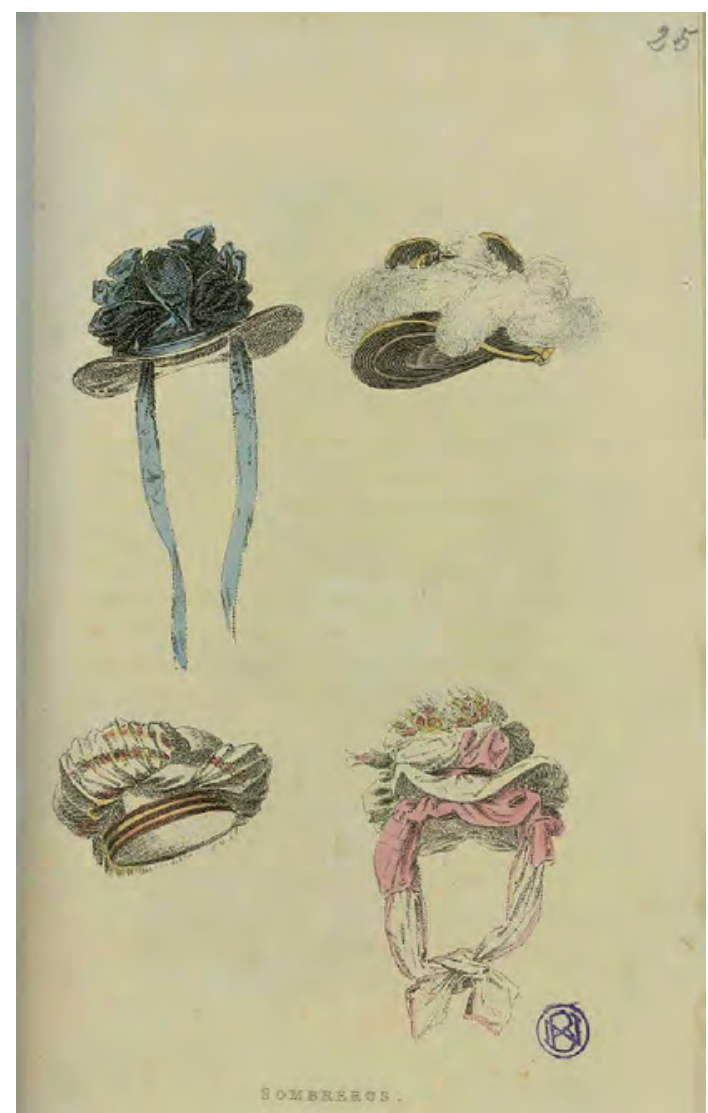

Fig. 1. Sombreros. Figurines Ingleses. Edición para España 1824-25. Biblioteca Nacional de España.

a que en España -por varios sucesos que a continuación detallaremos- sí que se desarrolló un singular gusto por lo inglés desde los primeros años del siglo XIX, el cual quedó plasmado en esas estampas procedentes de París y Londres.

La influencia francesa en el vestir mujeril ya estaba totalmente consolidada desde el siglo XVII dentro de las cortes de Europa, pues así se argu- mentaba en los primeros discursos sobre modas e indumentos a principios del siglo XIX dentro del Periódico de las Damas: "[...] la nacion que mejor ha sabido cultivar este ramo de la industria, para cebar, por decirlo asi, el lujo de los estados, se ha alzado con el imperio de la moda. La Francia desde el siglo diez y seis ha hecho tributarias á las demas naciones [...]". ${ }^{16}$ Aunque, por otro lado, sí que se confirma en este periódico que

la Inglaterra misma, que ha rivalizado siempre con la Francia en punto á la industria y á las artes; ha tenido que sucumbir en el ramo de la moda, no siendo la nacion que menos ha contribuido á la Francia; puesto que segun el testimonio de Lord Bolingbroke, ya en tiempo de Colbert, costaban á la Inglaterra mas de once millones de pesetas los objetos de moda llevados de Francia. ${ }^{17}$

En efecto, según este apunte y dada la época a la que se refiere (siglo XVIII), el crédito francés en la moda occidental estaba en su momento cumbre, aunque paralelamente el influjo inglés comenzó a penetrar en ciertas formas de vestir, como por ejemplo el denominado vestido femenino "a la inglesa". ${ }^{18}$ Este indumento fue consecuencia de la generalización de un vestido para la mujer sencillo y práctico que se originó en Inglaterra durante la segunda mitad del siglo XVIII, en contraposición al desmesurado lujo rococó francés de los decenios centrales de esta centuria. ${ }^{19}$ Esta anglofilia, popularizada durante las últimas décadas del setecientos por la duquesa de Devonshire, se basó en la sustitución de las artificiosas pelucas por unos sombreros y vestidos menos encorsetados de inspiración popular, ${ }^{20}$ lo cual ocasionó que desde París se comenzase a difundir al resto de naciones una nueva moda "a la inglesa" basada en un exquisito gusto por la simplicidad y naturalidad en las formas y diseño del vestido femenino.

El reseñado Periódico de las Damas - por cierto, el primero íntegramente dedicado a la mujer en España- ${ }^{21}$ nació dos años antes que la colección inglesa

16 Periódico de las Damas. 1822, n², p. 2.

17 Periódico de las Damas. 1822, nº 2, p. 2.

${ }^{18}$ Efectivamente, tras los nuevos impulsos del estilo neoclásico, como el interés que la sociedad asumió por la Antigüedad, en la Europa de mediados del Siglo XVIII se experimentó un cambio sustancial en el gusto y la estética que dominó el mundo de las artes y el estilo de vida de los europeos hasta los inicios del siglo XIX. La indumentaria reflejaría los nuevos postulados del Neoclasicismo, pues, como sabemos, la propia reina de Francia, María Antonieta, empezó a usar un vestido que reflejaba la sencillez y la idea rousseniana del contacto con la naturaleza. FUKAl, Akiko, 2006, p. 118.

19 SOUSA CONGOSTO, Francisco de, 2007, p. 23.

20 VELASCO MOLPECERES, Ana María, 2016, p. 49.

21 "Hasta ahora ha habido la disculpa que todos saben, y que la ignorancia y la supersticion han sido las dos áncoras en que se ha sostenido el despotismo; pero el presente, que gracias al cielo y á nuestro sabio sistema constitucional, hemos entrado en el rango de las naciones pensantes y escribientes, ¿por qué no han de tener las señoras españolas, como las francesas, las inglesas, las alemanas y otras, su periódico? [...]". Periódico de las Damas. 22 de abril de 1822, nº 16, p. 51-52. 
a la que nos referimos, a imitación de lo que ya se hacía por aquellos años en otros países. Lamentablemente, esta obra tuvo una vida corta y fugaz puesto que perduró solo durante seis meses, desde enero a junio del año 1822.22 Las entregas, como en el caso de las estampas de figurines, también estaban sujetas a suscripción y se realizaban en varios números de 48 páginas; en el caso de este periódico del 1 al 25. En cada ejemplar se insertaban igualmente artículos de noticias y comunicados sobre asuntos relacionados con la mujer dentro de la sociedad, en la historia, en sus costumbres..., algunos de ellos extractados de otras publicaciones extranjeras de símiles características. Además, se añadían secciones referentes a la frenética actividad política de ese periodo, a las que se sumaban otras de carácter literario, amenidades y, lo interesante, apartados dedicados a nuevas modas y buen gusto en el vestir y las artes decorativas. ${ }^{23}$ En ocasiones, en la última página aparecía un figurín del Observateur des Modes y del Petit Courrier des Dames tanto para el hombre como para la mujer. ${ }^{24}$

Por tales hechos, Madrid no fue ajena a estos fenómenos y desde las últimas décadas del siglo XVIII la villa y corte se comenzó a erigir como centro de recepción y difusión de todas las novedades parisinas en cuanto al vestir, como de otros tantos objetos destinados a una apariencia al gusto y a la moda del momento. ${ }^{25}$ Recordemos que otro de los prístinos ejemplos de difusión para el mercado de la moda que emanaba de París fue el de los figurines de Muestras de trages y muebles decentes y de buen gusto, de 1791, promocionado en el Diario de Madrid de ese mismo año, ${ }^{26}$ donde se exhibía esa dualidad ya en boga caracterizada por la amalgama de atractivos que sumaba lo francés bajo las innovaciones que llegaban al continente desde Londres. Esta colección, recogida dentro de algunos estudios actuales como el de Álvaro Molina y Jesusa Vega, ${ }^{27}$ supuso la incorporación española al nuevo consumo suntuario de diferentes artículos -indumentaria, muebles, cerámica, objetos de lujo, carruajes, etc.- procedentes de las publicaciones que ya estaban de total actualidad en aquellos países desde mediados del siglo XVIII. ${ }^{28}$

Barcelona tampoco estuvo al margen de las novedades parisinas. Para esta ciudad también se intentó publicitar una nueva colección de figurines parisinos, pues

no cediendo esta capital á ninguna otra del reino en la finura de su gusto por las modas, [...] se ha creido hacer un obsequio público, proporcionándole una suscripcion ó abono para una copia exacta del figurin ó estampa que viene de Paris en el diario llamado Petit Courrier des Dames [...]. . $^{29}$

Aunque finalmente la colección no tuvo éxito, tal como atestiguó el Diario Balear en meses posterio-

22 El último número, el 25, se publicó en el lunes 24 de junio de 1822 . En otros periódicos ideológicamente afines a este se anunció la finalización de la publicación: "este trabajo consagrado á la instrucción y recreo de las señoras españolas se ha suspendido por falta de despacho. Componiase de cartas familiares sobre las obligaciones propias de su sexo, de trozos históricos bien escogidos, de descripciones de las modas y de acertijos. No ha picado. ¿Y se pudiera estrañar cuando la Crónica de ciencias y artes juntó en España treinta suscriptores? Estos desengaños ofrecen reflexiones muy tristes sobre el atraso de la civilización de un país donde cuatro locos aspiran á una libertad desenfrenada". El Censor, periódico político y literario. $n^{\circ} 100,29$ de junio de 1822, p. 320.

23 En: «http://hemerotecadigital.bne.es/details.vm?q=id:0004978375\&lang=es» (consulta: 26-09-2019).

24 La inclusión del figurín masculino ocasionó cierta contrariedad entre las féminas españolas suscritas a este periódico, pues, según la observación del redactor: "sabiendo que las señoras no gustaban de otros figurines que los de mugeres, y en vista de que algunas nos han devuelto los de hombre, aunque solo hemos dado uno, prevenimos á nuestro corresponsal de Paris, que nos remitiese los de señoras solamente [...]". Periódico de las Damas. 22 de abril de 1822, n 16, p. 50.

25 Evidentemente, las élites de la capital como las de las diferentes provincias eran las principales consumidoras de estas estampas. El Periódico de las Damas - del lunes 22 de abril de 1822- desvelaba tal realidad en "lista de los suscriptores al periódico de las Damas", entre los que destacaban en Madrid las duquesas de Osuna y de la Roca, las condesas de Clavijo y Balazote, la marquesa de Villafranca, el conde de Montefuertes o el marqués de Espinardo, entre otros. Y en el resto de provincias las marquesas de Legarda, Malpica o Diezma, las condesas de Monterrón, de Montijo, de la Torre y la de Santa Ana...

26 Desde principios del año 1791 se anunció en este periódico la venta de esta colección. Durante todos los meses se avisaba a los suscriptores, tanto de Madrid como de otras provincias, las entregas de las siguientes estampas. En el $n^{\circ} 5$ del mes de enero, en la sección "Noticias particulares de Madrid", se dio el primer aviso para captar clientes, donde se explicaba que: "esta obra dará en varias estampas con la explicación necesaria un exacto y pronto conocimiento de los nuevos trages inventados para uno y otro sexo, fuera de España [...]". Diario de Madrid. $n^{\circ}$ 5, 5 de enero de 1791; $n^{\circ} 14,14$ de enero; $n^{\circ} 35,5$ de febrero; $n^{\circ} 49$, 18 de febrero, $n^{\circ} 66,7$ de marzo y $n^{\circ} 91,1$ de abril de 1791.

27 MOLINA, Álvaro; VEGA, Jesusa, 2004.

28 Estas publicaciones correspondían a The Ladie's Magazine en Inglaterra y Gallerie des Modes et Costumes Français en Francia, suponiendo el inicio de las primeras colecciones de figurines sobre artículos de moda y otros productos. MOLINA, Álvaro; VEGA, Jesusa, 2004, p. 137-38.

${ }^{29}$ Diario Balear, 7 de abril de $1827, n^{\circ} 7$, p. 5. 
res: "con motivo de no haberse reunido el número de suscriptores suficiente para dar al público la copia de los figurines del Petit Courrier se ha suspendido el proyecto [...]". ${ }^{30}$

Desde finales del siglo XVIII, las estampas que aparecen en estas publicaciones, sin contar con la novedosa obra española Colección de trajes de España, tanto antiguos como modernos... (1777), ${ }^{31}$ de Juan de la Cruz Cano y Olmedilla, pues esta evidencia unas láminas de tipos populares con trajes que se corresponden a un oficio o categoría social, ${ }^{32}$ supusieron uno de los antecedentes directos a las posteriores colecciones de figurines y revistas de moda y novedades que prosperaron durante todo el siglo XIX. De ahí la gran importancia de la aportación inglesa al buen gusto en el vestir, como en los objetos suntuarios de la mencionada colección de Figurines ingleses.

Dentro del continente, esta anglofilia en la moda no se basó única y exclusivamente en aspectos relacionados con el vestir, como ya indicamos, pues también influiría a otros campos como el teatro, ${ }^{33}$ la política o incluso en el pensamiento liberal, ya con mucho auge en la gran mayoría de naciones en los inicios del siglo XIX. En este último caso, se fundamentó en un nuevo liberalismo realista basado en la observación de los hechos sociales y en poner de manifiesto las diferencias nacionales. Así, Inglaterra también pasó a ser el paradigma en su forma de gobierno, el pensamiento filosófico o su propia historia, ${ }^{34}$ por lo que Francia fue una de las naciones más permeables en cuanto a estos postulados. Por tales hechos en España las influencias inglesas aparecieron en muchas ocasiones pasadas por el tamiz del país galo; en otros casos directamente por el flujo de comerciantes ingleses que llegaban a tierras españolas.
Paralelamente, entre 1791 y 1834, en España se acontecen diversos sucesos que hicieron nacer la prensa liberal. Surgen los primeros periódicos políticos, los cuales fueron suspendidos intermitentemente durante las primeras décadas del siglo XIX. ${ }^{35}$ En una de las fases liberalizadoras de este convulso periodo (Trienio Liberal, 1820-1823), ${ }^{36} \mathrm{y}$ en ese afán por instruir adecuadamente a la sociedad, se recomendaba desde la prensa destinada a las féminas españolas a que utilizasen, tanto en sus vestidos como en la decoración de sus hogares, una estética y líneas más depuradas y sencillas. De esta manera, el gusto quedaba más en consonancia con las nuevas ideas ilustradas que, desde las últimas décadas del Siglo de las Luces, ejercía ya el Neoclasicismo en conceptos de belleza, armonía o arte como ineludible símbolo de modernidad:

En materia de muebles de casa, como en todas las demas cosas, el verdadero buen gusto consiste en elegir los más útiles, los mas cómodos y de mayor duración [...]. Tú no debes pues, hija mia, perder de vista en la elección y arreglo de tus muebles esta armonía, esta perfecta correspondencia de unos con otros, y de todos con la utilidad y conveniencia doméstica, que es lo que, si no me engaño, esplican los ingleses con el confortable de una casa [...]. Huye de esos cortinajes y colgaduras de telas costosísimas [...], de esas sillerías de caoba que no presentan mejor aspecto [...], muebles todos que podrán bien anunciar la opulencia de sus dueños, mas no el talento y el buen gusto. ${ }^{37}$

Lo barroco y rococó pasaba a considerarse en este contexto, dentro de sus ya desmesuradas fórmulas, como algo recargado, antiestético o anticuado, pues lo neoclásico, como sabemos, supuso una reacción moral e intelectual contra la sociedad aristocrática del Antiguo Régimen derivada de la emergente burguesía. ${ }^{38}$ Tampoco hay que pasar por alto

30 Diario Balear, 1 de julio de 1827, n 1, p. 7.

31 Tras la precaria situación del grabado y la estampa popular en España durante el siglo XVIII, la Academia pensionó una estancia a París en 1752 a Manuel Salvador Carmona, Tomás López, Alfonso Cruzado y Juan de la Cruz Cano, lo cual supuso un avance de la técnica en esta materia, como también ayudó al desarrollo de la estampa popular y las imágenes de trajes. BOZAL, Valeriano, 1982, p. 9.

32 BOZAL, Valeriano, 1982, p. 9.

33 GUINARD, Paul J., 1984, p. 283-304.

34 VALERO SUANZES, Joaquín, 1992, p. 29-43.

35 RIEGO, Bernardo, 2001, p. 101-102.

${ }^{36}$ Este liberalismo español, dentro de sus fundamentos, fue deudor del liberalismo francés y, aunque en menor medida, del radicalismo inglés. JOVER ZAMORA, José María; GÓMEZ-FERRER, Guadalupe; FUSI AIZPÚRUA, Juan Pablo, 2001, p. 48.

${ }^{37}$ En este artículo del Periódico de las Damas, se da una breve lección de cómo amueblar una casa con el buen gusto requerido en ese momento. Periódico de las Damas, 4 de marzo de 1822, n 9, p. 1-12.

38 NOTARIO ZUBICOA, Carolina. "Septiembre. Modelo del mes. Frac neoclásico" (en línea). (Fecha de consulta: 10-07-2019). 
que paralelamente, tanto en el resto de países europeos como en España, existió desde principios del setecientos un nutrido núcleo de la sociedad antagónico a las ideas ilustradas y, posteriormente, al liberalismo, el cual vertía duras críticas hacia el exceso en el lujo o la utilización de modas extranjeras, $^{39}$ esencialmente las francesas.

Según las reflexiones de Carmen Abad-Zardoya, muy acordes con las ideas decimonónicas del mencionado Periódico de las Damas y su principal redactor, León Amarita Reverte, el gran interés que se produjo en el gusto por la novedad implicó que, en la mayoría de ocasiones, lo correcto, lo decente..., el buen gusto en general, estuviese casi siempre relacionado con la moda imperante en el vestir. Por tanto, los discursos sobre una adecuada y acertada elección en la decoración de una casa o el indumento femenino generalmente quedaban unidos en única causa: la influencia en estos de la moda. ${ }^{40}$ De esta suerte en España quedaron patentados unos criterios precisos sobre la elección de un gusto adecuado, digno y modesto desde finales del siglo XVIII, según las normativas suntuarias vigentes en la mayoría de países europeos.

\section{Factores determinantes de la influencia inglesa en España}

Ahora bien, y dentro de este mismo orden, ya hemos constatado que la aportación más reseñable de Inglaterra en cuanto a los asuntos del vestir quedó plasmada solamente en el frac masculino. Efectivamente, podemos corroborar que por lo general así fue según las fuentes consultadas y los diversos estudios previos realizados sobre moda o indumentaria dieciochesca o decimonónica. Pero en el caso español debemos tener en cuenta varios matices para comprobar que, en cierta medida, lo inglés estuvo muy palpable en los nuevos gustos de la alta sociedad de principios del ochocientos. Curiosamente, en la colección inglesa en la que nos basamos sí que se pueden constatar esas influen- cias en algunas estampas. Está claro que los figurines humanos no denotan ninguna desigualdad en cuanto a las modas que ya preexistían en las estampas parisinas del mismo periodo. ${ }^{41}$ Solamente disciernen en algo lógico y evidente: en el estilo y la estética de los modelos. La anterior colección, Muestras de trages y muebles decentes y de buen gusto, se corresponde a las modas previas al Directorio francés y al estilo imperio, mientras que la colección inglesa muestra una moda posterior a la era Napoleónica: el inicio de la moda romántica. ${ }^{42}$

Desde otro ángulo de ideas, también hay que tener en cuenta varios sucesos para entender estos postulados. Por un lado, hay que sumar a esta amalgama de ideas un hecho fundamental acaecido en España a principios del siglo XIX que atrajo, más aún si cabe, el interés por lo inglés: la invasión napoleónica y la consiguiente guerra de Independencia. La reacción espontánea frente a la ocupación francesa evidenció un clima de desprecio a todo lo que emanara del país vecino. Este hecho supuso un rechazo firme de los sentimientos del pueblo español al ver amenazados los resortes más entrañables de la actitud vital de cada individuo: las modas, las tradiciones, las costumbres, la religión, la tierra o el rey. ${ }^{43}$

Además, a esta circunstancia hay que añadir la alianza británica con España y Portugal contra la invasión francesa, lo que limó asperezas con este país históricamente enemigo, pues durante el siglo anterior se mantuvo un ambiente no digamos anglófobo, pero sí de atento recelo y curiosidad. Al respecto de las estampas, este asunto tiene mucho que ver con la confrontación franco-británica que señala Vega, pues a partir de estos momentos los caricaturistas ingleses centraron sus sátiras en láminas que reflejaban "la sumisión y entrega de los españoles contra el francés". ${ }^{4}$ Por contraste, y sin dejar pasar por alto estos motivos, paralelamente existieron unas relaciones comerciales muy activas entre España e Inglaterra gracias a esas mo-

\footnotetext{
39 CRESPO SÁNCHEZ, Francisco Javier, 2016, p. 137-155.

${ }^{40}$ ABAD-ZARDOYA, Carmen, 2012, p. 171-84.

${ }^{41}$ Por aquellos mismos años se difundían desde París los figurines del Observateur des Modes y del Petit Courrier des Dames, pues estos responden a los mismos patrones que las estampas inglesas.

${ }^{42}$ Estos asuntos estilíisticos quedan claramente definidos en la silueta que la mujer fue adquiriendo desde el periodo Rococó hasta los momentos previos al Romanticismo, que es donde encuadramos a los figurines de esta colección inglesa. En las modelos de las estampas inglesas de principios del siglo XIX podemos observar cómo la cintura femenina, gracias al uso del corsé, comienza a ir bajando y comprimiendo gradualmente la cintura, si bien en el periodo anterior, con el ligero y vaporoso "vestido camisa" correspondiente al estilo imperio, el talle del vestido quedó elevado hasta la parte inferior del busto femenino. La estética posterior a estos modelos corresponderá al desmesurado uso de las faldas gracias a la incorporación de las crinolinas, característica de la moda femenina plenamente romántica.

43 JOVER ZAMORA, José María; GÓMEZ-FERRER, Guadalupe; FUSI AIZPÚRUA, Juan Pablo, 2001, p. 59.

44 VEGA, Jesusa, 2018, p. 189.
} 


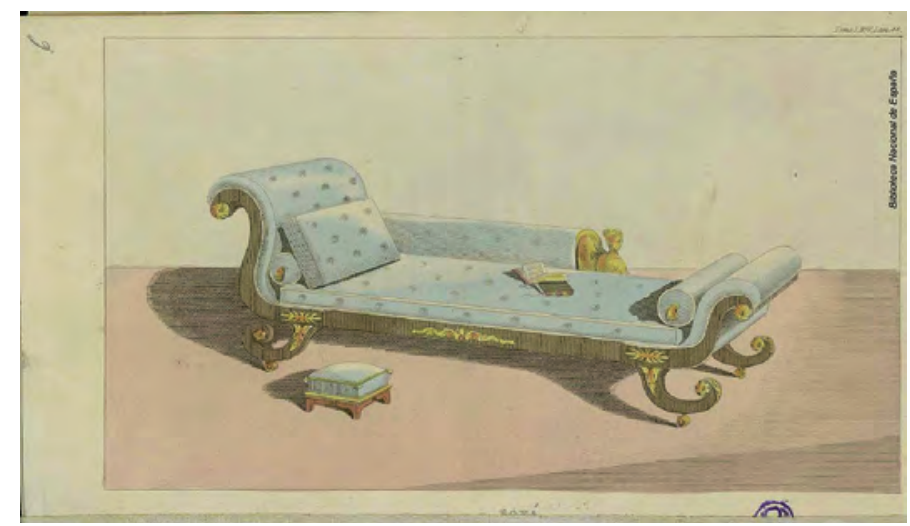

Fig. 2. Sofá. Figurines Ingleses. Edición para España 1824-25. Biblioteca Nacional de España.

das y objetos que penetraban en la Península desde sus principales puertos marítimos. ${ }^{45}$

Ante la gran demanda de piezas inglesas, especialmente de cerámica, los comerciantes de aquel país comenzaron a establecer sus puntos de venta o fábricas en España desde los primeros años del siglo XIX, como fue el caso del londinense Charles Pickman, quien fundó en 1822, tras morir su hermano William, ${ }^{46}$ la fábrica de cerámica de La Cartuja de Sevilla. Tampoco olvidemos que, según la hipótesis de Juan Antonio Lacomba, previamente a la mítica visión de la España romántica de principios del siglo $\mathrm{XIX},{ }^{47}$ patentada esencialmente por Francia tras la guerra de Independencia, fueron los ingleses los primeros en interesarse por el sur peninsular, quizás por el enclave gibraltareño. ${ }^{48}$
Efectivamente, así lo atestigua la prensa de finales del siglo XVIII y principios del XIX, la influencia inglesa en objetos suntuarios $y$, en menor medida, la moda fue una realidad en España. En el Diario de Madrid, entre los años 1788 y 1830, encontramos numerosas ventas de objetos casi siempre denominados "a la inglesa" o de "última moda", por lo que fue un hecho constatado que desde los últimos decenios del setecientos lo procedente de Londres comenzaba a experimentar una creciente demanda dentro las artes decorativas y suntuarias, como también en algunos complementos del vestir. Un primer ejemplo lo hallamos en la relación de gastos para la boda del que ostentaría el VII condado de Luque, Cristóbal Fernández de Córdoba y Barradas, con María Antonia Pérez del Pulgar y Pérez del Pulgar. Este listado del año 1789 nos reseña que se emplearon "doscientos cincuenta y dos reales de vellón, que cuatro de junio de ochenta y siete, pagué a D. Gerónimo Pérez Elizalde [...], por el valor de seis bandejas inglesas charoladas". ${ }^{49}$

\section{Prensa "a la moda": decoración, mobiliario, coches, trajes...}

En el mencionado Diario de Madrid se ofertaban gran cantidad de prendas que denotaban la actualidad en su procedencia: "chalecos á la inglesa de moda para Sras. bordados, á 70 rs. Dichos para hombres con dibujos nuevos á 75". ${ }^{50} \mathrm{Al}$ hilo de lo expresado, recordemos que desde el siglo XVIII una de las prendas que en diversas ocasiones complementaba al vestido femenino, como también al masculino, se le comenzó a denominar con un vocablo inglés, el spencer: una especie de chaquetilla o casaca corta de manga larga para poner inmediatamente encima de la cotilla o vestido. Asi-

45 GUINARD, Paul J., 1984, p. 283-304.

${ }^{46}$ Desde 1810, William Pickman se estableció como comerciante de cerámica y cristal inglés en la ciudad de Cádiz, desde donde distribuía al resto de España todas las novedades importadas desde Inglaterra.

47 Hasta los primeros decenios del siglo XIX, la imagen que de España se tenía en el resto de Europa fue un tanto negativa y perniciosa. Tras la guerra de Independencia, los franceses, en parte, redescubrieron este territorio del sur europeo al reconvertir esa visión negativa en positiva, aunque no dejara de ser un tanto superficial. En el Periódico de las Damas muestra un buen ejemplo de cómo se comenzó a gestar esa nueva imagen a principios de siglo, e incluso de cómo la moda francesa también se inspiró en ciertas peculiaridades de la idiosincrasia española: "en el año 1820 nuestra tan dichosa como inesperada revolucion sorprendió á toda la Europa; de modo que cuando nadie se acordaba de nosotros sino para dolerse de nuestra vergonzosa esclavitud, ó para burlarse de la lentitud que llevamos en la carrera de la civilizacion, repentinamente se oyó por todas partes con gusto el nombre de España, y no hubo un estrangero que no envidiara la discrecion y firmeza de caracter de los españoles. Nuestros buenos vecinos los franceses, acostumbrados á llamar español, aunque no lo sea, á cualquier objeto feo ó de mal gusto, vieron entonces con distintos ojos nuestras virtudes morales; y pasando como suelen de un estremo á otro, quisieron imitar hasta las extravagancias de nuestro trage nacional [...]". Periódico de las Damas, 4 de marzo de 1822, n 9, p. 29-30.

${ }^{48}$ LACOMBA, Juan Antonio, 1992, p. 163-177.

${ }^{49}$ Cuenta de los gastos de la boda de Cristóbal Fernández de Córdoba Barradas [futuro VII Conde de Luque]... Archivo Histórico de la Nobleza, LUQUE, C. 340, D. 27, f. 5v.

50 Diario de Madrid, 6 de julio de 1790, n 18, p. 740. 
mismo, coches, forlones o berlinas de última moda, nuevos o de segunda mano, también comenzaron a estar de actualidad dentro de los anuncios de este diario al ser calificados, como siempre, con el estilo según el origen: a la inglesa, a la francesa o a la española.

En anuncios, grabados o descripciones de los carruajes que aparecían en estos ejemplares de difusión, casi siempre se refieren a la inglesa cuando se quería garantizar que era un objeto "a la última"; es decir, que era algo moderno y novedoso. Así lo atestigua uno de tantos anuncios que el periódico madrileño publicitaba en su sección de ventas: "en la calle del Pez casa de Antonio Contreras, maestro de hacer coches, se vende uno á la inglesa nuevo, de ultima moda, vestido de paño blanco, con muelles á la polinaca, y cigüeñas enterizas". ${ }^{51}$ De la misma manera, la cerámica y los objetos suntuarios vienen igualmente reseñados con esta denominación a la hora de difundirlos en la prensa: "en el despacho principal de este periodico se dará razón de la venta de una partida de loza inglesa de pedernal de buena calidad [...]".52 Está claro que denominar a cualquier objeto de lujo a la inglesa le otorgaba cierto valor extraordinario.

Este afán por lo británico en las nuevas modas suntuarias también se expresa en una noticia de 1786 sobre la "descripción del Coche nuevo de gala de la Serenísima Princesa nuestra Señora, y noticia de los artífices que han trabajo en el todo de su construcción". Por la cronología, es evidente que se trata de un presente destinado a agasajar a María Luisa de Parma, por aquel entonces aún Princesa de Asturias. Como indica la nota que recoge esta información sobre el nuevo coche regalado a la futura reina: "el corte de la caxa es á la moda inglesa [...]", y se completaba con una decoración en la parte delantera, justo a los lados del pescante del vehículo con: "[...] dos chicotes corpulentos de talla vestidos á la inglesa, con sus sombrerillos y plumages". ${ }^{53} \mathrm{Co}$ mo sabemos, desde la segunda mitad del siglo XVIII, la Revolución Industrial de Inglaterra marcó un punto de inflexión en la historia, pues hizo que se modificaran diversos aspectos de la vida cotidiana. De esta suerte, el siglo XIX abre sus puertas a múltiples adelantos en la industria, la economía o el transporte. Por este hecho, todo lo proveniente de este país se consideraba como un innegable símbolo de modernidad, como fue el caso de las nuevas estructuras para berlinas o carruajes que ya se habían desarrollado con extraordinario auge dentro de Inglaterra y otras naciones europeas.

Antonio Durán, descendiente de una reconocida estirpe dedicada a la herrería y cerrajería, ${ }^{54}$ fue el que ofreció a la princesa de Asturias esta suntuosa carroza a la inglesa para que, a la vez, afirmara a toda la nobleza madrileña el buen prestigio de su oficio, al igual que mostrar en el vehículo todas las novedades y adelantos que llegaban y aprendían desde la industriosa ciudad de Londres los artífices españoles, pues de este modo garantizaban y perpetuaban su buena reputación.

No menos importantes son las reseñas que se realizan en estos diarios para la venta de muebles, pues también hallamos numerosos testimonios que confirman el buen gusto y modernidad en la procedencia anglosajona del mobiliario para el hogar, entre los que descuellan los siguientes: "la rifa del exquisito Tocador, fabricado en Londres, tasado por los mas hábiles Artistas de esta Corte [...]".55 Como también en la venta instrumentos musicales: "[...] un fortepiano, ${ }^{56}$ del mejor autor de Londres, hecho venir de encargo [...]", ${ }^{57}$ : "[...] un excelente

51 Diario de Madrid, 1 de abril de 1791, $\mathrm{n}^{\circ}$ 91, p. 370.

52 Diario de Madrid, 1 de abril de 1791, n 91, p. 370.

53 La realización de este coche estuvo bajo la dirección de Antonio Durán. Los artífices que intervinieron en el conjunto fueron: Juan Antonio García y Fernando Rodríguez como oficiales de coches, Pedro Rodríguez de Arellano como tallista, Esteban de Agreda como escultor, José Petit como pintor charolista y dorador, Fermín Mendiluce para el trabajo de platero y broncista, Dionisio Salinero como guarnecedor, Rodrigo de la Mesa en la labor de dorador a fuego, Pedro Bello con oficio de guarnicionero, Manuel Camino para los bordados, Juan Delgado como cordonero y Manuel Sanz de Velasco para el trabajo de pasamanero. Diario curioso, erudito, económico y comercial, 20 de julio de 1786, n 20, p. 83-86.

54 Antonio Durán era sobrino del prestigioso relojero Ramón Durán e hijo de Manuel Durán "Herrero y Cerrajero de las Caballerizas del Rey nuestro Señor; tiene bien acreditado en esta Corte su ingenio por el primor, solidez y hermosura de todas quantas piezas salen de su taller, que nada desmerecen al lado de las que vienen de Londres". En Memorial literario, instructivo y curioso de la corte de Madrid, tomo VII, $\mathrm{n}^{\circ} \mathrm{XXIX}$, mayo de 1786.

55 Diario de Madrid, 4 de marzo de 1796, $n^{\circ} 64$, p. 260.

56 Desde la segunda mitad del setecientos, encontramos artífices españoles dedicados a la construcción de este instrumento donde se muestran las innovaciones y novedades inglesas. El pianoforte también era conocido en España como "piano de mesa". El sevillano Juan del Mármol fue el más afamado pianero desde finales del XVIII y principios del XIX que trabajó para el rey y la nobleza española, pues fue pensionado en Londres por Carlos III para perfeccionar la técnica de construcción de este instrumento. MARTíNEZ LÓPEZ, Víctor Javier, 2018, p. 33-51.

57 Diario de Madrid, 19 de febrero de 1795, n 50, p. 202. 
piano forte construido en Londres [...]". ${ }^{58}$ Asimismo, los objetos para el adorno mujeril aparecen en numerosas publicidades de artículos suntuarios, como por ejemplo los abanicos a la inglesa. ${ }^{59}$

\section{La colección de estampas}

La obra nos presenta treinta y ocho grabados coloreados, de los cuales treinta y uno son de figurines femeninos que muestran un nutrido catálogo de tipologías de vestidos, según el momento, ocasión o etiqueta pertinente: trajes de mañana, tarde, paseo, tertulia, casa, visita, baile, gala o convite. Las siete estampas restantes corresponden a complementos del vestir (cuatro sombreros), mobiliario y decoración para el hogar -escritorio, sofá, sillas y cortinas- y artículos de lujo (dos carretelas). Asimismo, incorpora una breve descripción que alude al objeto mostrado en cada lámina. De estos textos descriptivos únicamente aparecen veintisiete páginas que acompañan a los dibujos.

En los figurines de indumentaria se pormenoriza el tipo de género utilizado, color, materiales, adornos, joyas o complementos. En esta colección, en muchos casos, la reseña no está correlativa a la estampa. En total, aunque desordenados, hay diecisiete grabados con sus correspondientes reseñas; por tanto, las restantes láminas de figurines humanos (catorce) vienen sin ninguna explicación. Además, sobran tres textos descriptivos -"Traje de mañana", "Traje de tarde" y "Traje de baile"- que no hacen referencia ni se corresponden con ninguna de las estampas sobrantes. Es posible, dada la forma de adquirir los grabados mediante suscripción y reparto semanal en los despachos de los diarios o imprentas, que esta colección no se llegase a completar o, por el contrario, que se vendiesen algunas de las láminas sueltas sin ningún texto. ${ }^{60}$

Los figurines van identificados y numerados en el margen superior derecho con el tomo, el número correspondiente y el número de la lámina; en cambio, no todas vienen identificadas. Las numeracio- nes de los grabados, según la encuadernación, tampoco van correlativas, están estructurados aleatoriamente dentro de la colección. Se aprecia que, posteriormente, y a lápiz, se han numerado -del 1 al 51- ordenadamente según aparecen encuadernados o según el orden de compra, puesto que también guardan el orden de esta paginación manual los textos descriptivos.

Tal como sucedía en las anteriores colecciones -como en la ya mencionada Muestra de trages y muebles...-, en la inglesa también se incluye mobiliario y dos nuevos artículos dentro de los grabados: "Carretela de verano" y "Carretela abierta". En las estampas de muebles se muestran las láminas: "Mesa y estante", 61 "Sofá", "Cortinas de ventanas"62 y "Silla de gabinete, Sillón, Silla de estrado". Casualmente, en una de estas ("Carretela abierta") viene reseñado el nombre del grabador: "ingraved by S. Mitan". ${ }^{63}$ Es la única estampa en la que aparece este dato, el cual nos puede dar a entender que todas las demás láminas, posiblemente, fuesen grabadas por este célebre autor, empleado de la Casa Ackermann. Ciertamente, las estampas que muestran los figurines femeninos mantienen prácticamente las mismas características estilísticas, composición, dibujo y rasgos fisionómicos.

En la lámina de "Sombreros" [Fig. 1], observamos cuatro tipologías de este complemento, además de los que ya se añaden en los vestidos de los figurines. En casos concretos sí que se especifica, dentro de la descripción que acompaña al grabado, el estilo de cada sombrero como, por ejemplo, a lo "María Estuardo". Este diseño, según los postulados románticos basados en la búsqueda de las historias legendarias e identidades de cada país, se inclina hacia los tocados renacentistas de ciertos personajes ilustres, como en este caso la mencionada soberana de Escocia (1542-1567). De la misma manera, aparecen otros con influencias exóticas, tales como "turbante tártaro" o "a la española antigua". Esto tiene mucho que ver con los nuevos gustos decimonónicos por lo extranjero y singular. Las nuevas ex-

58 Diario de Madrid, 22 de julio de 1819, n²03, p. 120.

59 Diario de Madrid, 22 de julio de 1819, $n^{\circ} 203$, p. 120.

60 En el Periódico de las Damas, que como ya hemos advertido también funcionaba a suscripción, se nos aclara la manera y forma de llegada y venta de las estampas: "Damos los figurines guardando el órden con que se dan en Paris, y van sueltos en cada periódico para que las señoras los apliquen á el número en que se habla de la moda que representa la estampa, ó para que si gustan puedan formar de ellos una colección separada [...]". Periódico de las Damas, 1822, nº 5, p. 48.

${ }^{61}$ En este grabado aparece un escritorio-librería, dos rinconeras, una de ellas al estilo de una columna clásica y dos mapas enrollables colgados encima del escritorio.

${ }^{62}$ Se muestran tres ventanas con diferente diseño y tamaño (la central más ancha) y sus correspondientes modelos de cortinas. En todas ellas aparece un paisaje diferente de fondo tras el cristal.

63 Samuel Mitan (1786-1843) fue grabador que trabajó para la empresa fundada por el editor Rudolph Ackermann. Véase LEE, Sidney (ed.), 1894. 
pediciones a Oriente y América durante la Modernidad imbricaron el apogeo del comercio y la navegación, la creación de una diplomacia internacional y del Estado Moderno, el cual gestionó, entre sus señas de identidad, el traje y sus transformaciones. De esta suerte, la indumentaria fue utilizada como un mecanismo para establecer el dominio sobre otros pueblos, por lo que, gracias a estas imágenes y a la creación de la imprenta, se exportó el traje o influencias de cada país, ${ }^{64}$ desarrollándose asimismo la universalización en el vestir. Por este hecho, en las modas de principios del siglo XIX se experimentó una profunda búsqueda por lo identitario de cada nación.

Prosiguiendo con las estampas y textos de esta colección, encontramos una muy concluyente, la dedicada al sofá [Fig. 2]. En ella, sin duda, aduce notoriamente al gusto por lo inglés que se experimentaba durante aquel periodo, como a la incorporación de un moderno asiento para dos o más personas dentro de los grandes salones para los momentos de tertulia. Además, en la descripción también se alude al uso de este nuevo mueble para momentos de descanso y lectura, del mismo modo que se expresaba sutilmente una crítica hacia la mala formación de los españoles y, al mismo tiempo, se les incitaba a que, como los ingleses, se instruyeran por medio de la lectura:

El sofa figurado en esta estampa adorna decentemente un estrado, y ofrece al mismo tiempo un descanso cómodo. El libro representado en la estampa alude a la afición a la lectura que reina en Inglaterra. A la verdad que semejante inclinación está propagadísima en este país. Todos los Ingleses leen; por donde quiera se ven libros, y a veces se admira al viagero de hallar tanta instrucción en los artesanos, y en otras clases pobres. ${ }^{65}$

En la estampa de "Carretela de verano" [Fig. 3] se evidencia nuevamente los nuevos adelantos y la influencia inglesa en este medio de transporte gracias a esa pasión tan de la aristocracia y la burguesía de aquel país de entender y disfrutar los paseos y la vida en la campiña:

Este elegante carruage está mui en uso en Inglaterra, sobre todo durante la estación en que los Señores y ricos propietarios residen en sus casas de campo. Cuando quieren divertirse en manejar las riendas, se colocan en el asiento delantero, y cuando no, en el otro. De él se sirven también para ir a cazar, y

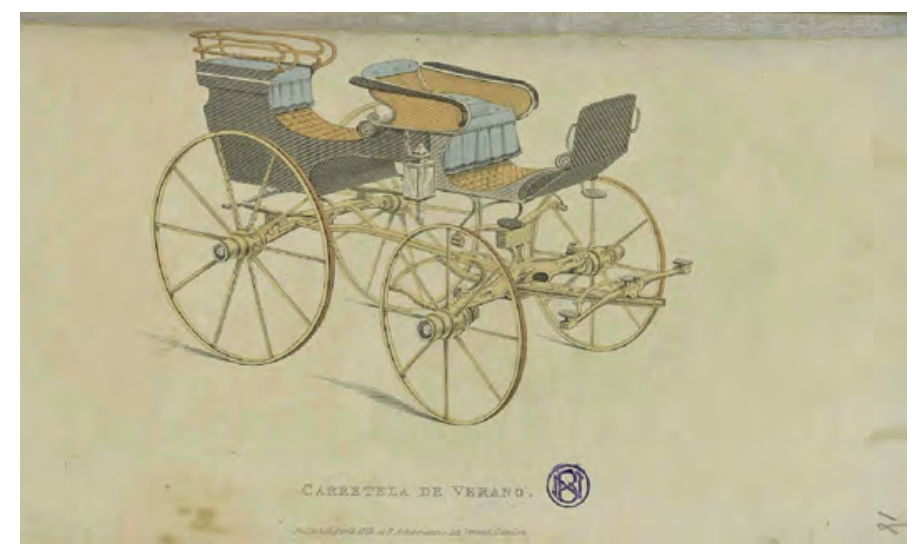

Fig. 3. Carretela de verano. Figurines Ingleses. Edición para España 1824-25. Biblioteca Nacional de España.

para conducir a las Señoras a las excursiones campestres de que tanto gustan en este pais. ${ }^{66}$

En el mobiliario para el hogar se declara que lo moderno ya quedó totalmente asociado al refinado gusto inglés dentro de las artes decorativas. La lámina que muestra los tres modelos de sillas [Fig. 4] nos certifica los nuevos gustos por la simplicidad en las líneas, formas y estéticas que ya se hacían palpables desde las últimas décadas del siglo XVIII, al igual que la exquisitez de los ingleses por su refinado gusto por el mobiliario:

Estos tres muebles manifiestan los progresos que han hecho en Europa las artes de adorno, y el gusto con que se aplican a los objetos que se emplean en los usos comunes de la vida. El sillon tiene todo el esplendor y magnificencia que requiere un mueble destinado a grandes escenas de lucimiento y brillo, y puede ocupar dignamente la testera de un tribunal supremo, o de un cuerpo legislativo. La silla de estrado corresponde acertadamente a su obgeto, y reúne a la elegancia de las formas la novedad del dibujo. La silla de gabinete es sencillísima y modesta, y representa uno de los innumerables modelos que se encuentran en los almacenes de muebles de Londres. ${ }^{67}$

Desde finales del siglo XVIII, en las secciones de noticias y avisos del Diario de Madrid ya quedó consolidado el interés por lo inglés en las nuevas modas y buen gusto para los objetos suntuarios. En este caso, para la venta de muebles nuevamente apare-

\footnotetext{
64 VELASCO MOLPECERES, Ana María, 2016, p. 72-73.

${ }^{65}$ ACKERMANN, Rudolph (ed.), 1824-25.

${ }^{66}$ ACKERMANN, Rudolph (ed.), 1824-25.

67 ACKERMANN, Rudolph (ed.), 1824-25.
} 


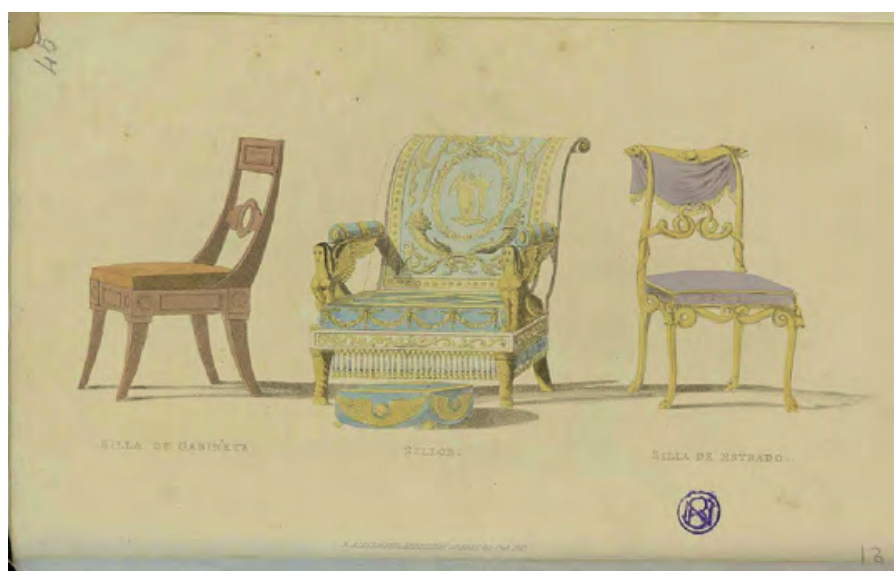

Fig. 4. Silla de gabinete, sillón y silla de estrado. Figurines In gleses. Edición para España 1824-25. Biblioteca Nacional de España.

cen diversas reseñas sobre este estilo: "en la calle de Silva frente al Banco Nacional, se venden sillas á la Inglesa, con brazos de ultima moda, camapés, y sofás, todo con equidad". ${ }^{68}$

Como ya advertimos, los figurines femeninos también nos constatan ciertas novedades que ya se desarrollaban en ambos países, Francia e Inglaterra, y que posteriormente se extendían al resto de naciones europeas. Entre ellos destacan las diversas referencias que se hacen a un modelo de vestido generalmente destinado para el paseo, la dulleta ${ }^{69}$ [Fig. 5]. Una especie de bata para el abrigo al estilo de las que se utilizaban para estar dentro de casa, las cuales estaban realizadas en diversos materiales y diseños: sarga de Francia, seda, terciopelo, gros de Nápoles o paño, dependiendo para qué momento o para qué estación del año. De los seis modelos, prácticamente todos guardan la peculiaridad básica de esta tipología de vestido: este queda abierto por delante. Además, para este traje la manga siempre es larga, el cuello muy alto y cerrado y el figurín siempre que viste esta prenda de abrigo porta un sombrero.

Los vestidos para la mañana, tarde, casa, visita o tertulias, generalmente, también guardan unos rasgos similares en la forma, estética, decoración o complementos, que se asemejan notoriamente a los reseñados anteriormente para el paseo, e incluso en los tejidos empleados. En las estampas de trajes que se destinan para fuera del ámbito del hogar, el figurín suele incorporar de nuevo el sombrero o algún gorro, turbante o cofia; ${ }^{70}$ asimismo, la manga también es larga y tampoco lleva mucho escote. Para los modelos de trajes diseñados para el interior de una vivienda -por ejemplo, los de visitas o tertulias-, la normativa suntuaria aconsejaba unos colores más claros y tejidos menos espesos. En algunos casos, los vestidos de estos últimos grabados aparecen con un diseño de amplio escote y manga corta "a pabellones", sobrepuesta a una manga larga de crespón blanco o simplemente con manga corta.

El derroche de lujo y suntuosidad de los figurines expuestos en esta colección, como es normal, viene de la mano de los modelos de trajes para baile, convite o gala. En los ocho ejemplos que aparecen en esta serie, la mujer, a excepción de dos que llevan una especie de tocado a modo de turbante, aparece sin ningún tipo de sombrero, solo peinada con rizos y exornada con flores o plumas. ${ }^{71}$ Solamente van acompañados con la descripción del vestido tres figurines, los restantes (cinco) no llevan ningún texto. Además, hay una página descriptiva ("Trage de baile") que no se corresponde con ningún grabado de esta colección. Evidentemente, los dos figurines que aparecen con una indumentaria de gala -uno de ellos lo acompaña una descripción del vestido-son los más ricos en ornamentación. Este figurín [Fig. 6], reseñado con el número 20, porta un

68 Diario de Madrid, 6 de mayo de 1794, nº 126, p. 4.

69 La prensa de la época nos matizaba que esta prenda: "aunque la estacion del invierno es la mas á propósito para usar las dulletas, la benignidad del tiempo que esperimentamos, ha sido causa de que aun no se haya determinado la moda acerca de ese traje. Hasta ahora se hacen cerradas por delante con un espeincer por encima [...]". Periódico de las Damas, 1822, n 1, p. 34.

70 "Se usan ahora muchos sombreros de felpa blanca, y los mas de ellos se adornan con cordon de oro, ó de plata. En muchos se acostumbra poner plumas blancas rizadas: en otros ramos de hojas de encina con bellotas gordas. [...] Los turbantes se hacen con mucha frecuencia de colores fuertes, añadiendo el oro, la plata, ó el acero según lo indique el buen gusto, y para toda ceremonia se agregan los brillantes. Los mas se enriquecen con un plumero blanco bien conocido en la corte y que en frances se llama esprit". Periódico de las Damas, 1822, nº 5, p. 35-36.

71 Se aconsejaba para los peinados de baile "[...] mucha fruta menuda como grosellas, cerezas, y uvas. Sigue el estilo de los rizos gruesos, aunque muchas señoritas llevan el pelo liso ó sin rinzo, y abierto en el medio de la frente distribuido igualmente en ambos lados". Periódico de las Damas, 1822, n 5, p. 35. 


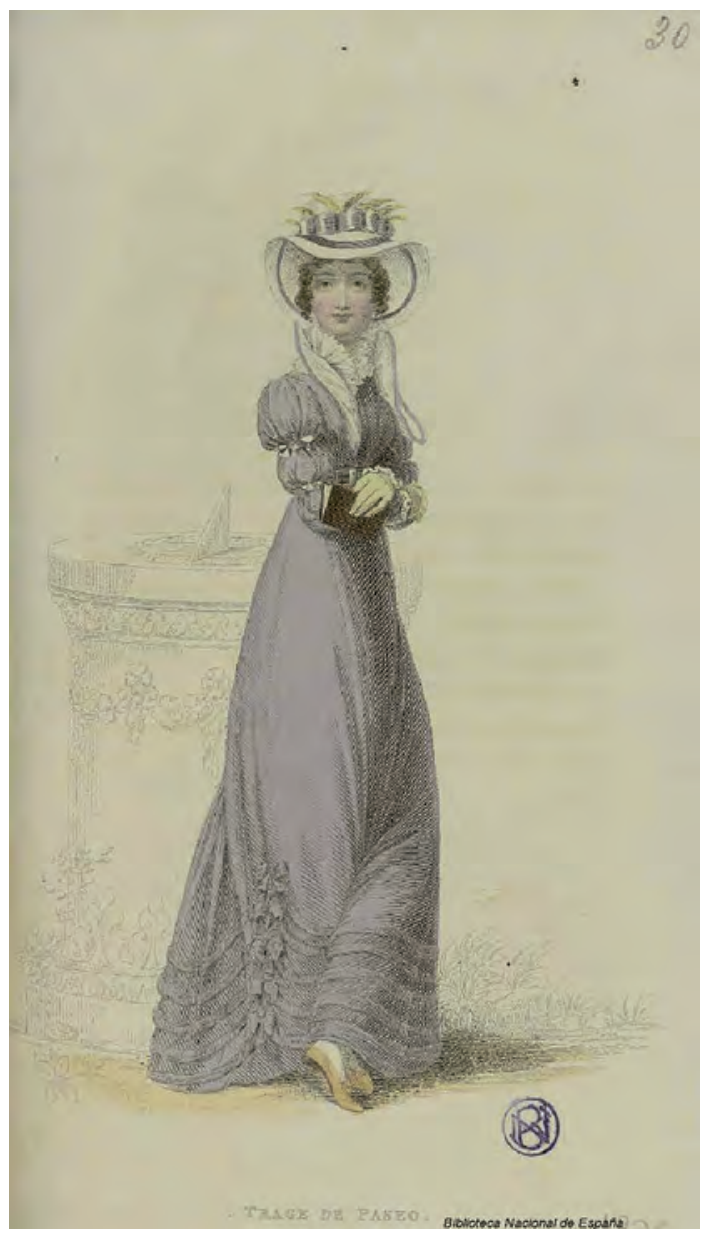

Fig. 5. Traje de paseo. Figurines Ingleses. Edición para España 1824-25. Biblioteca Nacional de España.

trage de crespon de china punzó con lentejuelas de oro; sobrepuestos de encage de oro, en el pecho hasta los hombros; guarnicion ancha de lo mismo; manga corta terminada del mismo modo. Turbante de crespon del color del trage y oro, con buches de raso punzó; pluma de este color al lado derecho; pañolon de encage blanco; pendientes, braceletes y collar de perlas; guantes de Francia y zapato de raso blanco. ${ }^{72}$

Tras legislar y verter diversas críticas y comentarios nada halagüeños hacia los desmesurados lujos y los usos de modas extranjeras desde el siglo XVIII,

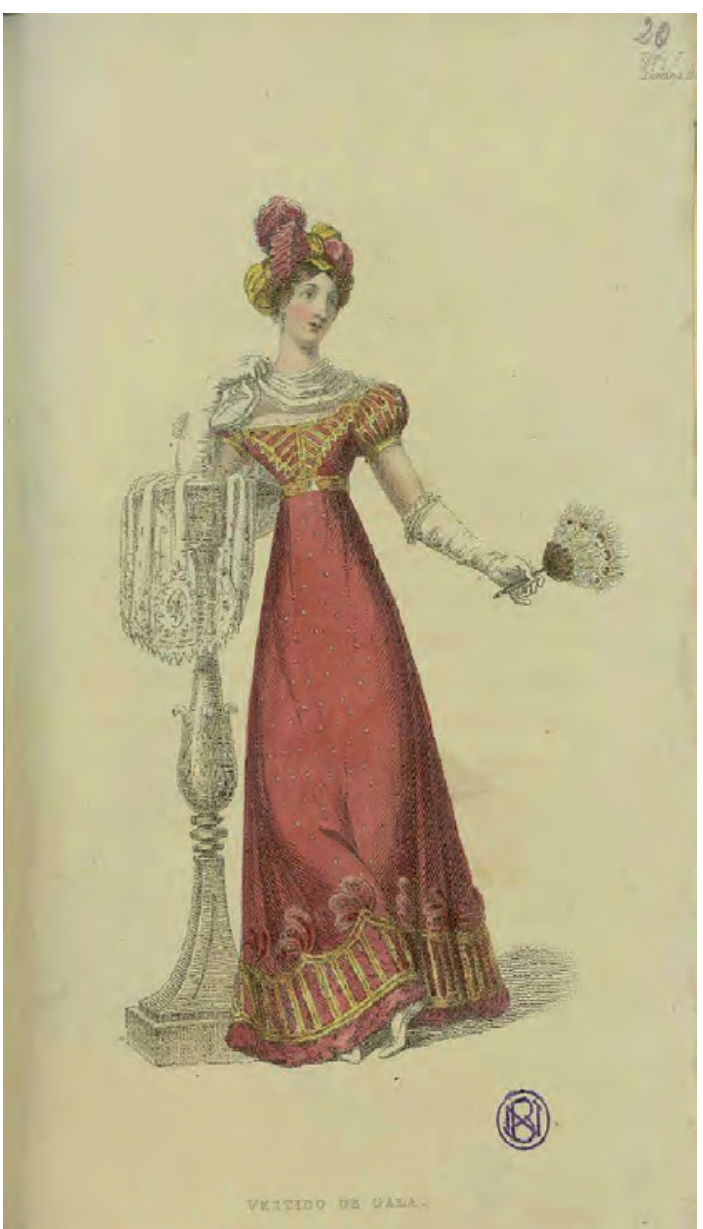

Fig. 6. Vestido de gala. Figurines Ingleses. Edición para España 1824-25. Biblioteca Nacional de España.

la propagación de los figurines de modas en España ocasionó, según los datos que arroja la prensa de los primeros años del siglo XIX, un malestar general entre algunos maestros sastres de Madrid, pues con las estampas de novedades llegaron las modistas a la corte, ${ }^{73}$ principalmente francesas. Tal como se aseguraba en una carta firmada con las siglas "Q. S. M. B. = P. S. T", sobre aquellas "maestras intrusas", hubo cierto recelo y duda desde este gremio madrileño de la forma de trabajar de estas modistas extranjeras: "[...] y no puedo mirar con in-

72 ACKERMANN, Rudolph (ed.), 1824-25.

${ }_{73}$ Sobre este asunto el Periódico de las Damas se hacía eco de algunas casas de modistas madrileñas: "no tiene Madrid que envidiar en el dia á ninguna otra corte Europea, la afluencia de personas extremamente diestras en el ramo de la industria perteneciente á modas; pues se halla surtido de casa en donde se trabaja en cuantos objetos puede inventar el buen gusto, con la misma elegancia y perfeccion que en París. Tales son la casa de la señora doña Vicenta, calle del Carmen número 1 , cuarto principal esquina á calle de la Salud: la de madama Próspera puerta del Sol número $4^{\circ}$ : la de madama Hubert calle de la Montera número $7^{\circ}$ almacen de modas de París [...]. Doña María Pia Villannova, calle de la Montera número 28 , modista solo de vestidos. Madama Casadaban, calle de la Montera número 38. Madama Rencuel, calle de la Montera, número 43, modista solo de vestidos. Doña María Perez, modista y florista, se fabrican excelentes flores y plumas de todas clases asi para hombres como para mugeres, Red de S. Luis número 21". Periódico de las Damas, 1822, nº 4, p. 31-32 y nº 5, p. 37 
diferencia el ultrage que se les hace á muchos buenos maestros, que hay entre mis compañeros, con especialidad en la delicada obra de mujer". Por tanto, según se deja entrever en esta carta, los sastres, ante la amenaza extranjera, pretendían acreditar su buen hacer

pero á pesar del gran partido que tienen, no faltan señoras juiciosas que desengañadas conocen la diferencia de nuestras obras, y nos prefieren. [...] Pues además del perjuicio que causan por nuestro ramo, no es de menos cuenta el que causan a otros. ${ }^{74}$

Para finalizar, debemos matizar que cada grabado, como norma general, muestra un único figurín aislado; es decir, solamente aparece la mujer con el vestido correspondiente al momento del día. A diferencia de algunas estampas dobles de la colección francesa Muestras de trages y muebles decentes $y$ de buen gusto, de 1791, en los que inserta junto al figurín humano una lámpara, jarrón o reloj, en la colección inglesa hay láminas que, según el ambiente que recrea cada tipología de vestido -tertulia, casa, mañana baile o gala- también incluye algún elemento decorativo a la moda que sirve de complemento a este, tal como un jarrón, sofá, silla, mesa o espejo, algunos de ellos casi esbozados. Estos objetos, a la vez que desvelan las últimas novedades suntuarias, sirven exclusivamente de apoyo a la imagen para reforzar aún más el ámbito y el momento en que se debe insertar el vestido, pues la mujer puede aparecer sentada en el sofá de una sala de tertulia, apoyada en una silla o rinconera de un salón de baile o mirándose a un espejo en un tocador. Asimismo, en algunas estampas que se adjuntaban en el Periódico de las Damas aparece un doble figurín que muestra el vestido por delante y por detrás. ${ }^{75}$ Por supuesto, la calidad de los grabados de la colección inglesa es muy superior a los que se muestran en la colección parisina.

Igualmente, en Figurines ingleses. Edición para España encontramos dos singulares grabados que difieren de otras colecciones, pues en ellos observamos el nuevo concepto decimonónico de la mujer como "ángel del hogar". En uno -con el número 41-, con un traje de casa, el figurín femenino aparece junto a un niño al que le enseña a leer, y en el segundo -numerado también a lápiz con el 48-, con un vestido para la tertulia, se representa a una niña subida en un taburete mientras juega con el tocado de su madre. Evidentemente, son escenas que ambientan momentos de cotidianidad dentro del hogar donde los niños también estaban presentes bajo la tutela materna. ${ }^{76}$

Sin lugar a dudas, y como hemos atestiguado a lo largo del desarrollo de este estudio, gracias a las diversas noticias en la prensa de finales del siglo XVIII y principios del XIX, complementadas con este ejemplo de láminas, los influjos ingleses estuvieron palpables en diversas colecciones de figurines, principalmente en algunos objetos suntuarios pues las últimas novedades y adelantos en mobiliario, textiles, artes decorativas o vehículos, casi siempre, estaban relacionadas con las importaciones que llegaban desde Londres. Uno de los impulsores de lo inglés, el mencionado editor Rudolph Ackermann, promovió un cambio de paradigma cultural basado en la influencia británica, mucho más moderna, frente a la francesa puesto que su obra apuntaba hacia el progreso científico y tecnológico y el consumo burgués, entre otros muchos asuntos. ${ }^{77}$

\section{Referencias bibliográficas}

ABAD-ZARDOYA, Carmen. "La dimensión cotidiana y social del buen gusto. Espacios y objetos de sociabilidad en el siglo de la Civilización". En: ARCE, E. (coor.). et al. Simposio: Reflexiones sobre el gusto. Zaragoza: Instituto Fernando el Católico, 2012, p. 171-84.

ACKERMANN, Rudolph (ed.). Figurines ingleses. Edición para España 1824-25. Londres: Rudolph Ackermann, 1824-25.

BELLUGA Y MONCADA, Luis. Carta pastoral que el Obispo de Cartagena, escribe a los Fieles de su Diócesis a cada uno en lo que le toca, para que todos concurran a que se destierre la profanidad de los trages, y varios, e intolerables abusos, que ahora nuevamente se han introducido. Murcia: Jayme Mesnier, 1711.

BOZAL, Valeriano (ed.). Colección General de los Trages que en la actualidad se usan en España principiada en el año 1801 en Madrid. Madrid: Visor Libros, 1982.

\footnotetext{
74 Diario de Madrid, 30 de octubre de 1803, n 304, p. 1213.

75 Se advertía en uno de los últimos ejemplares de este periódico que "deseando agradar á las pocas damas que hasta ahora han contribuido á sostener nuestra empresa, y para demostrar el interes con que buscamos su instruccion y recreo en este papel, único que las esté dedicado en España, antepondremos en adelante á los figurines del Observador de las modas, que hasta aqui pensábamos que eran los mejores ó los mas acreditados entre las petimetras de Paris, otros que hemos visto después en la Estafeta de las Damas, los cuales sobre ser mas frescos ofrecen la ventaja de presentar los trages por entero, duplicando la figura, y dejando de este modo ver su forma por delante y por detrás". Periódico de las Damas, 3 de junio de 1822, n²2, p. 21.

76 Por estas fechas, ya existían diferentes tratados en Inglaterra, Francia y España para la educación de los de los niños, en los que se especificaba que la madre asumiría la función de educadora dentro del hogar para transmitir a sus hijos los principios morales y las pautas de conducta que rigen en la sociedad de aquellos años. PANADÉS Y POBLET, José, 1877.

77 DURÁN LÓPEZ, Fernando, 2015, p. 3.
} 
CRESPO SÁNCHEZ, Francisco Javier. "Vestidos y adornos: la crítica a las apariencias externas a través de la prensa española (finales del siglo XVIII-siglo XIX)". Estudios Humanísticos. Historia, 2016, n 15, p. 137-155.

DURÁN LÓPEZ, Fernando. "Semblanza de Rudolph Ackermann (1764-1834)". En: http://www.cervantesvirtual.com/obra/rudolph-ackermann-1764-1834/ (consulta: 10-10-2019).

FUKAl, Akiko (coor.). Moda: la colección del Instituto de la Indumentaria de Kioto: una historia desde el siglo XVIII al siglo XX (trad. Montserrat Ribas). Köln: Taschen, 2006.

GUINARD, Paul J. "Sobre el mito de Inglaterra en el teatro español de fines del siglo XVIII: Una adaptación de Valladares de Sotomayor". Anales de literatura española, 1984, n 3, p. 283-304.

HARRIS, Katherine C. "The Legacy of Rudolph Ackermann and Nineteenth-Century British Literary Annuals", 2015. BRANCHcollective.org. En: http://www. branchcollective.org/?ps_articles=katherine-d-harristhe-legacy-of-rudolph-ackermann-and-nineteenthcentury-british-literary-annuals (consulta: 27-06-2019).

JOVER ZAMORA, José María; GÓMEZ-FERRER, Guadalupe; FUSI AIZPÚRUA, Juan Pablo. España: sociedad, política y civilización (siglos XIX-XX). Madrid: Ediciones Debate, 2001.

LACOMBA, Juan Antonio. "La mirada ajena: Andalucía vista por otros". Estudios Regionales, 1992, n 44, p. 163-177.

LEE, Sidney (ed.). "Mitan, James". Dictionary of National Biography. London: Smith, Elder \& Co., 1894.

MARTíNEZ LÓPEZ, Víctor Javier. "Representación de un pianoforte de mesa español en las colecciones del
Museo Nacional del Prado. El pianero Juan del Mármol". Imafronte, 2018, n² 25, p. 33-51.

MOLINA, Álvaro; VEGA, Jesusa. Vestir la identidad, construir la apariencia. La cuestión del traje en la España del siglo XVIII. Madrid: Ayuntamiento de Madrid, 2004.

NOTARIO ZUBICOA, Carolina. "Septiembre. Modelo de mes. Frac neoclásico". En: http://www.culturaydeporte. gob.es/mtraje/biblioteca/publicaciones/publicacionesperiodicas/modelo-mes/ediciones-anteriores/2005.html (consulta: 10-07-2019).

PANADÉS Y POBLET, José. La educación de la mujer, tomo I. Barcelona: Jaime Seix y Compañía, 1877.

PENA GONZÁLEZ, Pablo. "Indumentaria en España: el periodo isabelino (1830-1868)". Indumenta: Revista del Museo del Traje, 2007, n 0, p. 95-106.

PENA GONZÁLEZ, Pablo. El traje en el Romanticismo y su proyección en España, 1828-1868. Madrid: Ministerio de Cultura, 2008.

RIEGO, Bernardo. La construcción social de la realidad a través de la fotografía y el grabado informativo en la España del siglo XIX. Santander: Universidad de Cantabria, 2001

SOUSA CONGOSTO, Francisco de. Introducción a la historia de la indumentaria en España. Madrid: Ediciones Istmo, 2007.

VALERO SUANZES, Joaquín. "El liberalismo francés después de Napoleón (de la anglofobia a la anglofilia)". Revista de Estudios políticos, 1992, n 76, p. 29-43.

VELASCO MOLPECERES, Ana María. Moda y prensa femenina en la España del siglo XIX. Valladolid: Ediciones 19, 2016

VEGA, Jesusa. "La cambiante imagen de Napoleón en España: del retrato imperial a la bestia apocalíptica y su desmemoria". Ars longa, 2018, n²7, p. 183-193. 
